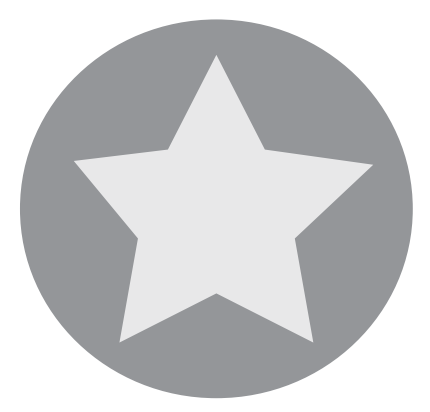

En 1982, el autor publicó en la revista Hablemos de cine un extenso análisis de la famosa y polémica cinta de Nagisa Oshima, quien falleció a inicios de este año. A modo de homenaje al realizador japonés, publicamos la nota en esta edición de Ventana Indiscreta.
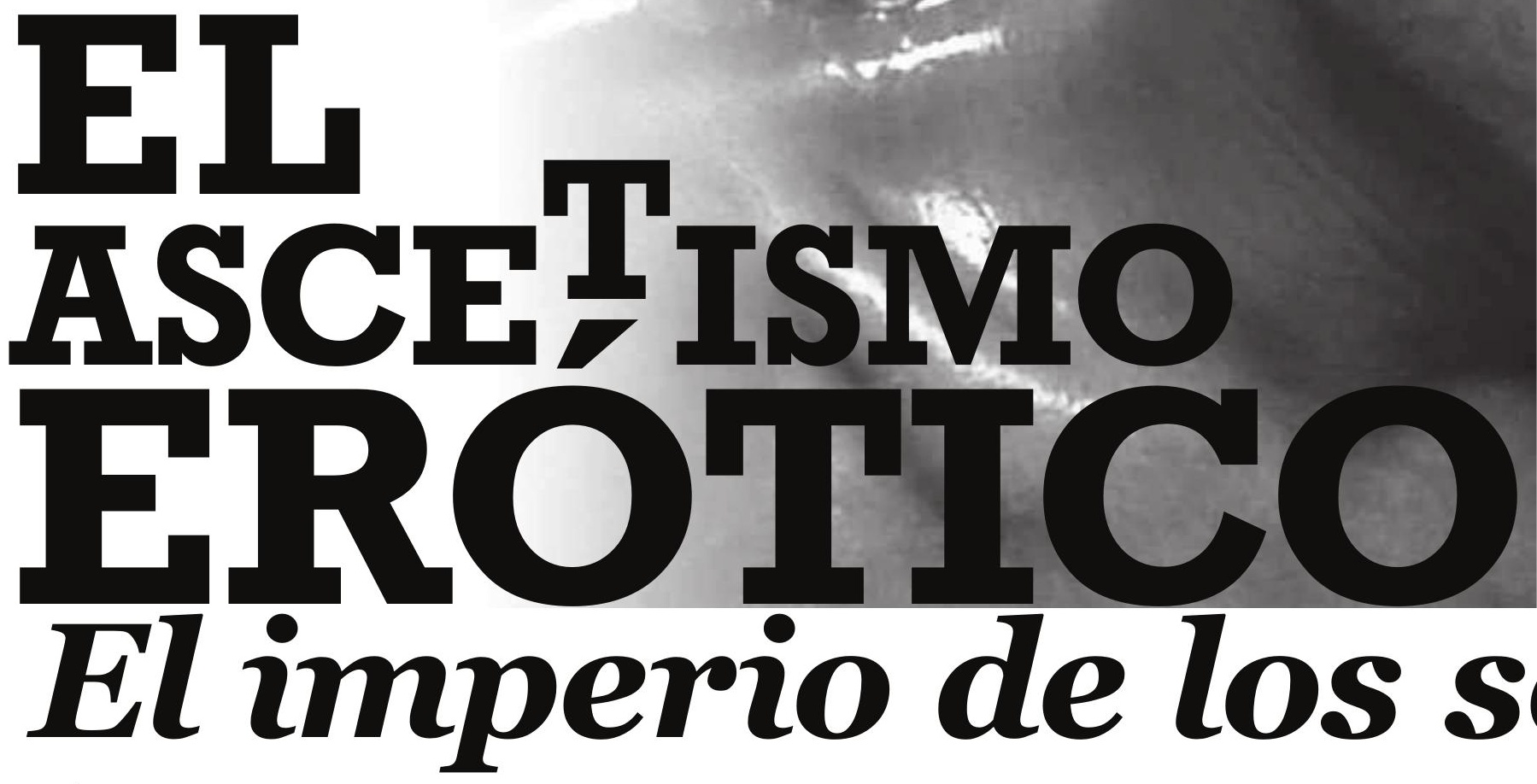

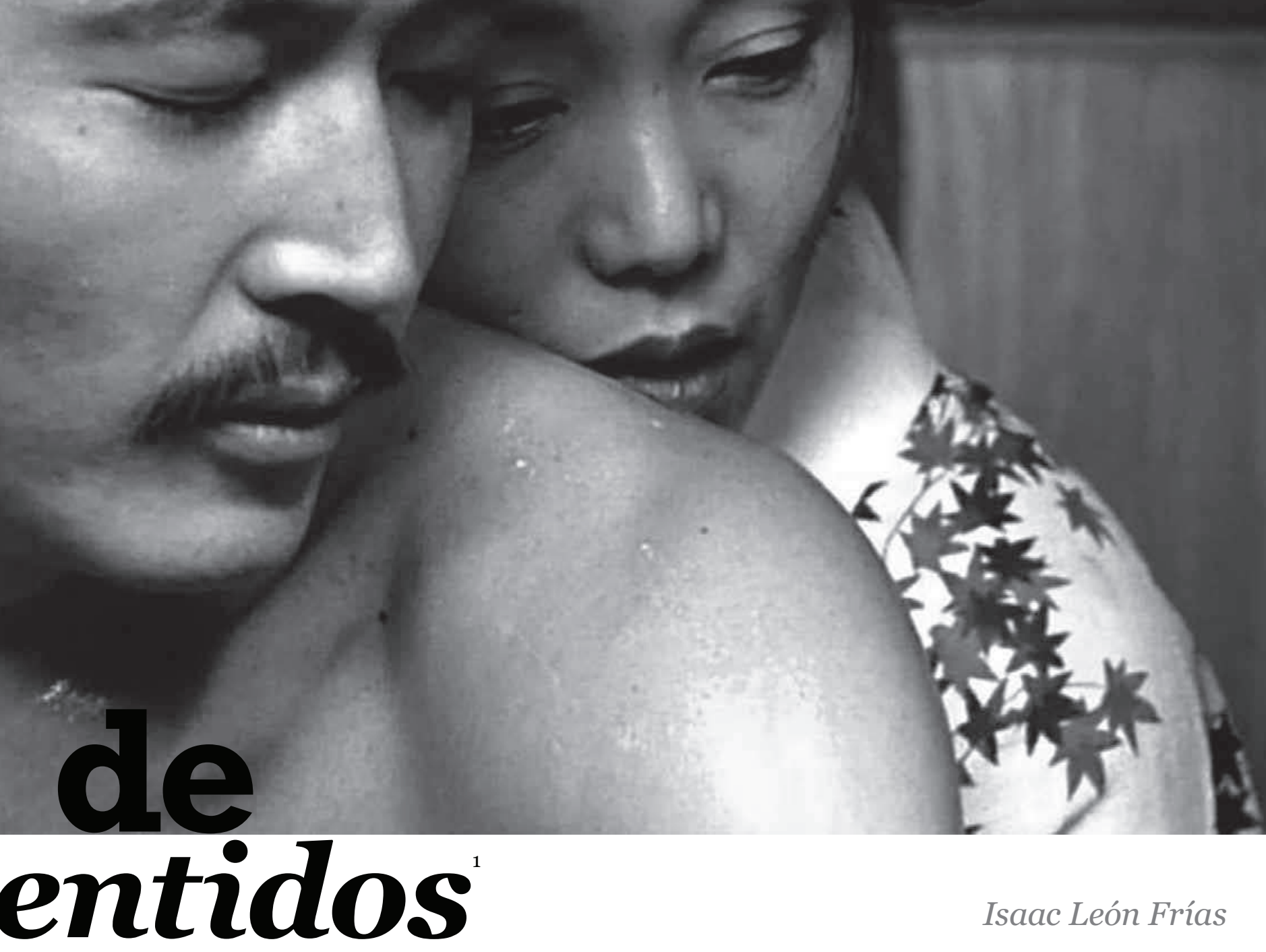

Isaac León Frías 
Una primera consideración: El imperio de los sentidos (Ai no corrida, 1976) llegó a Lima en medio de la apertura censora y obtuvo un previsible éxito comercial y menos protestas de lo que se podía esperar. Por ahí, entre otras cosas, una columnista que se quejó de "esos japoneses degenerados" y una carta en contra del filme que nos colocaba a Huayhuaca y a mí (a propósito de las críticas publicadas en los semanarios Oiga y Caretas) al lado de Sade, Masoch, Bataille y Oshima, honor que se agradece pero que, obviamente, es absolutamente inmerecido.

No fue, claro, la extraordinaria calidad de la cinta de Oshima la que favoreció su acogida, vista, además, en una copia deplorable que afecta la totalidad del color. Si en vez de esta se hubiera estrenado El imperio de la pasión (Ai no Borei, 1978), la siguiente película de Oshima, muy distinta, pese al título, a la que hemos visto en Lima, es muy probable que hubiera asistido una mínima parte de ese público ávido que llenó el cine Roma y luego el Imperio. Más que en ningún otro caso - pues, definitivamente, Último tango en París y Decamerón llegaron tarde-, El imperio de los sentidos se ha beneficiado por el incremento de la ola porno en el país y la curiosidad consecuente. Pero no creo que se haya sentido defraudado ese públi- co mayoritario que fue a ver el filme desconociendo, antes y después, la existencia de Oshima y que probablemente no ha visto otro filme japonés en su vida ni quizás lo verá en el futuro. ${ }^{2}$ Pero así como, y las estadísticas lo confirman, no dio gato por liebre a las expectativas voyeuristas, tampoco creo que haya complacido en extremo las predisposiciones habituales más ligadas a un porno llano y sin mayores complicaciones o a un sadomasoquismo espectacular y ostentoso. Y es que El imperio de los sentidos supone una propuesta erótica novedosa que así como se aparta de la menor concesión a la moral institucional, así también se 


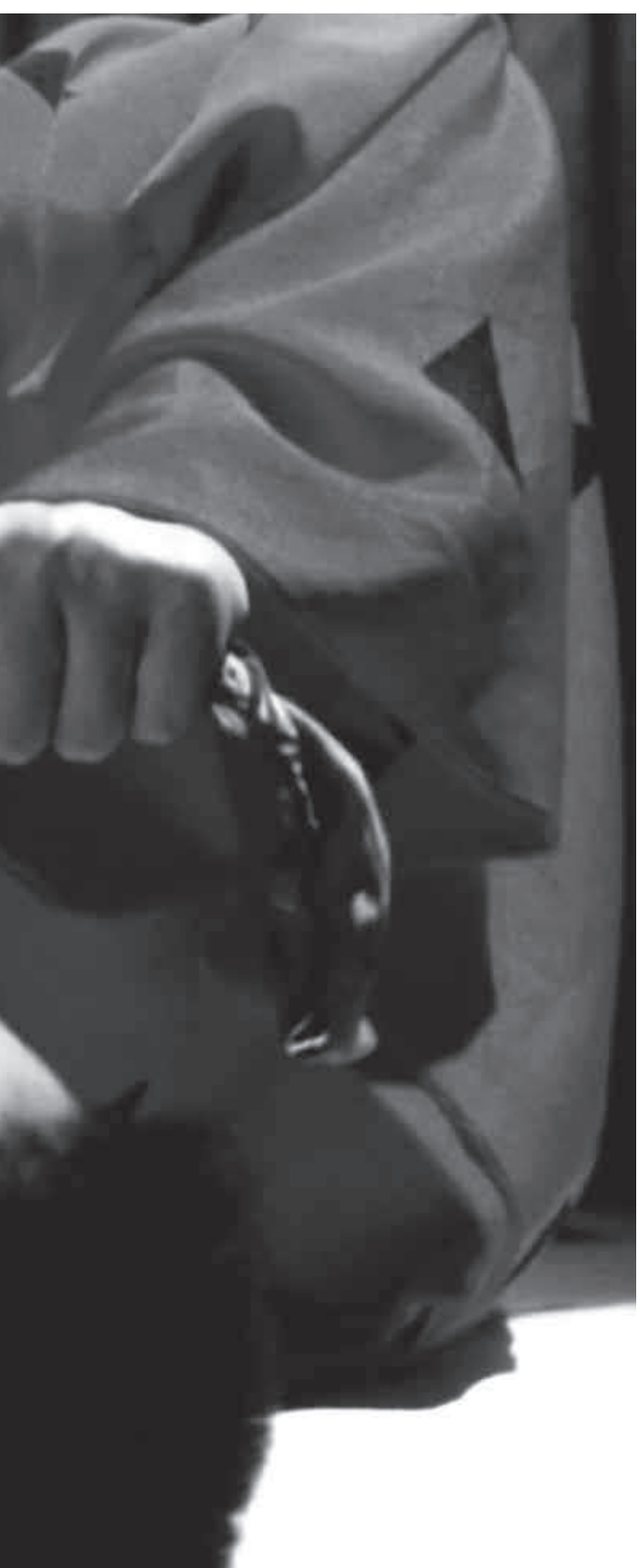

aleja del exhibicionismo comercial del cine porno.

\section{La cuestión pornográfica}

Se ha suscitado en torno a nuestro filme la inveterada polémica entre lo erótico y lo pornográfico, polémica que ahora, cuando lo abiertamente pornográfico está dejando de ser un tabú -a medias, claro está; si no por qué las funciones de trasnoche- probablemente interesa mucho menos que antes. No creo que se trate de un asunto central ni que de él dependa una valoración más clara de la pelí- cula. Si El imperio de los sentidos es pornográfica, en el sentido de "obscena” o sexualmente provocadora, lo es en buena hora. Ya es el momento de dejar el uso del término pornográfico como un adjetivo despreciativo, sinónimo de vulgaridad o mal gusto. Si $E l$ imperio de los sentidos contribuye a revisar el uso de la expresión estará haciendo un buen aporte a la desmitificación, en el fondo moralista y bienpensante, de la connotación negativa que le atribuyen a la pornografía, incluso quienes dicen defender la liberación del erotismo en el cine.

Ahora bien, lo que sí conviene diferenciar, pues tiene que ver con lo que define y singulariza la película, es su forma de abordar la materia sexual. Tanto en el soft core (sexo trucado, pura simulación, ausencia de penes erectos y de penetraciones reales) como en el hard core (sexo sin truco), la exposición de cuerpos desnudos y el despliegue de actos sexuales, verdaderos o fingidos, se reduce a una repetición simple y llana, como cualquier dispositivo mecánico, sin emoción ninguna, relegada a una corporeidad maquinal. Un acto sucede al otro, cambian las posiciones y el número de participantes en un tono bastante monocorde. Casi como si se tratara de marionetas en actividad, ya lo decía Huayhuaca en el ensayo El yo dividido de Woody Allen, en el número anterior de Hablemos de cine. Incluso, en la mayor parte del cine porno, la cámara se neutraliza al máximo, como quien filma el funcionamiento de un organismo cualquiera. Por aquí hay una curiosa similitud entre el cine porno y el llamado cine científico, donde también se produce esta mediatización linguiística en función del seguimiento expositivo.

En el hard core típico no hay siquiera un relato propiamente dicho, o si lo hay es un apunte, un borrón inicial, un simple pretexto. Lo mismo podemos decir de la mayor parte del soft core que hemos visto en los años recientes (la serie alemana de las colegialas, Melodía de amor, etcétera). El relato es una línea tan frágil que, como en las películas de artes marciales, sirve para trazar un relleno transicional, a manera de leves bisagras, con el fin de encadenar en un caso las escenas de acción violenta, en el otro las escenas de acción sexual.

\section{En El imperio de}

los sentidos la

exposición de cuerpos desnudos

y actos no pasa por

la complacencia

habitual de los

hard core, no hay

muchos encuadres

que muestren

copulaciones en

forma completa, incluso el

desnudamiento integral va

\section{llegando de modo}

progresivo.

En ambos casos (el porno y las "artes marciales") se produce una cierta regresión del espectador a un estado de receptividad casi infantil, paradójicamente a una neoinocencia, como cuando el niño llega a una situación de expectación y asombro puros en las escenas de acción (de los telefilmes, de las películas convencionales de género) y no tolera los momentos de descanso o tregua del relato.

En la serie de Enmanuelle, supuesta justificación "artística” del género, se ha querido legitimar, por un lado, una estética del erotismo que no es otra cosa que una mezcla de poster de lujo e imágenes de Harper's Bazaar y Lui, adornadas por el señuelo del exotismo oriental y una filosofía del placer que parece más bien una versión del Kamasutra al alcance de todos los ojos. Una vulgarización Reader's digest de una erótica-de-fin-de-semana-en el-oriente-de-burguesía-europea. ${ }^{3}$ Erótica elevada a la categoría de supremo valor. Pero también se 


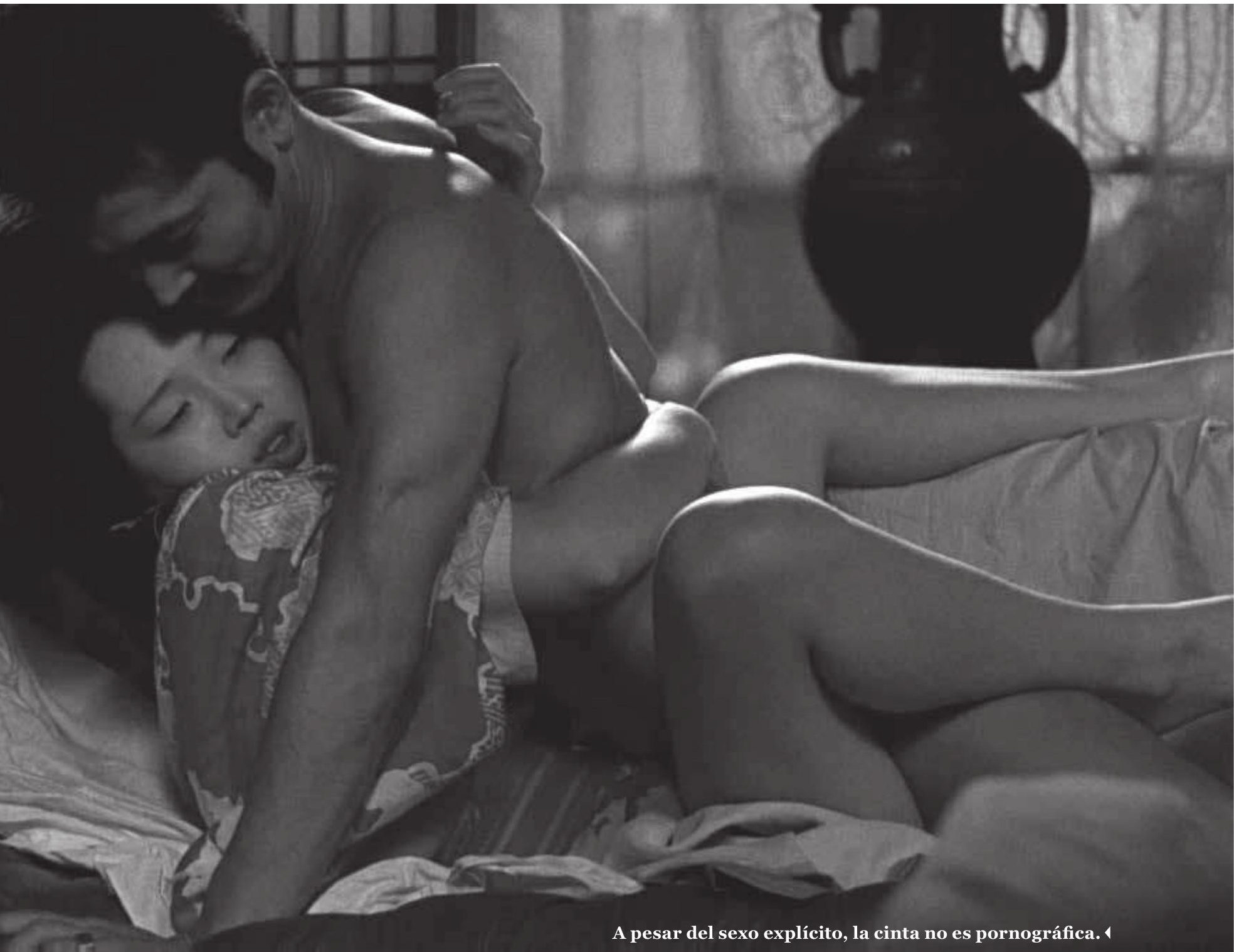

nentes del ascetismo de la puesta en escena: Bresson y Dreyer en Europa, Ozu y Mizoguchi en la propia tierra de Oshima.

\section{La liturgia de los cuerpos}

El imperio de los sentidos cuenta la historia de una pasión absorbente, la que experimentan un acomodado señor con una joven sirvienta-prostituta que forma parte del cortejo de criados de la casa. Pasión que progresivamente se va haciendo excluyente y que culmina, luego de una larga ordalía erótica, en la muerte (aceptada) de Kichi-san por estrangulamiento, como expresión simbó- lica del orgasmo límite. Al final, un narrador señala que la película se inspira en un caso real que ocurrió en Tokyo en 1936. Antes, solo hay un dato que ubica la acción en el periodo imperial-militarista que el Japón vivió en esos años y es la escena en que Kichi-san camina en el sentido contrario de una hilera de soldados que desfilan por una calle. Este único dato expresa la negación de una época histórica y de lo que esta representó para la vida del Japón del siglo XX. Pero la exclusión de datos contextuales, el apartamiento de toda instancia exterior a la que va a ir consumiendo las energías de los personajes indica que, más allá de una coyuntura histórica precisa, lo que la pasión de los personajes está negando es todo el orden institucio- nal. En la afirmación de una libertad de entrega se niegan los patrones sexuales y familiares aceptados o tolerados y, por lo tanto, se violenta el Orden, la Ley, la Norma y, en definitiva, ese principio de realidad y razón que los fundamenta. La pasión de los amantes, en una de las mejores expresiones de amour fou que el cine haya ofrecido, destruye el menor resquicio de "normalidad", de allí que, entre otras cosas, sea una pasión colindante con la muerte, suprema negación del erotismo codificado por la norma social y moral, del erotismo en alianza con el principio de realidad.

También en la perspectiva señalada, el filme de Oshima radicaliza la postura solo en principio antiinstitu- 
cional del cine pornográfico (el sexo no con los fines de la reproducción sino del puro placer), pues lo que en este suele ser una válvula de escape, asume en El imperio de los sentidos toda su potencialidad transgresora y liquidadora. A partir de esa negación el filme instala su normalidad, la normalidad del deseo librado a sus posibilidades y apurado hasta su límite que es, justamente, la falta de límites y, por ende, una vez más, la muerte. No hay topes ni barreras para el deseo, los hay sí para la materialización del deseo, es decir, el placer, y de eso es que da cuenta $E l$ imperio de los sentidos: del intento de prolongar al máximo un estado de placer a fin de cuentas inestable y precario, estado que compromete por entero la existencia de los per- sonajes en juego. Que la película se reduzca a un caso de satiriasis y ninfomanía como, con un criterio gruesamente psicologista, se ha sostenido, es como reducir a claves geométricas una pintura cubista. No es un "caso clínico" el que la película plantea y es errónea cualquier interpretación en esa línea que conduce, además, a conclusiones anacrónicamente moralistas. Al contrario de una supuesta degradación o degeneración por el sexo, la experiencia placentera límite lleva más bien a Sada y Kichi-san a una suerte de proceso "santificador", como ha sugerido el mismo Oshima, a un martirologio laico, a una "purificación" por el placer. Esta santificación sui géneris es la que encontramos por otros caminos y con resquicios re- ligiosos totalmente ajenos al filme de Oshima, en muchos personajes de Buñuel (Arturo de Córdova en Él, Francisco Rabal en Nazarín, Silvia Pinal en Viridiana, etcétera) y, obviamente, Bresson (Un condenado a muerte se escapa, Al azar Balthazar, Mouchette, etcétera).

La "purificación” ascendente de los personajes encuentra su expresión en la decantación de la puesta en escena. En ella, el espacio se concentra y el tiempo se diluye, otros indicadores, además, de la negación de la realidad y de la Historia. Los límites del encuadre recortan cercanamente la corporalidad restallante y en tensión de los actores, excepcionales Tatsuya Fuji y, sobre todo, Eiko Matsuda como Sada, verdadero mo-
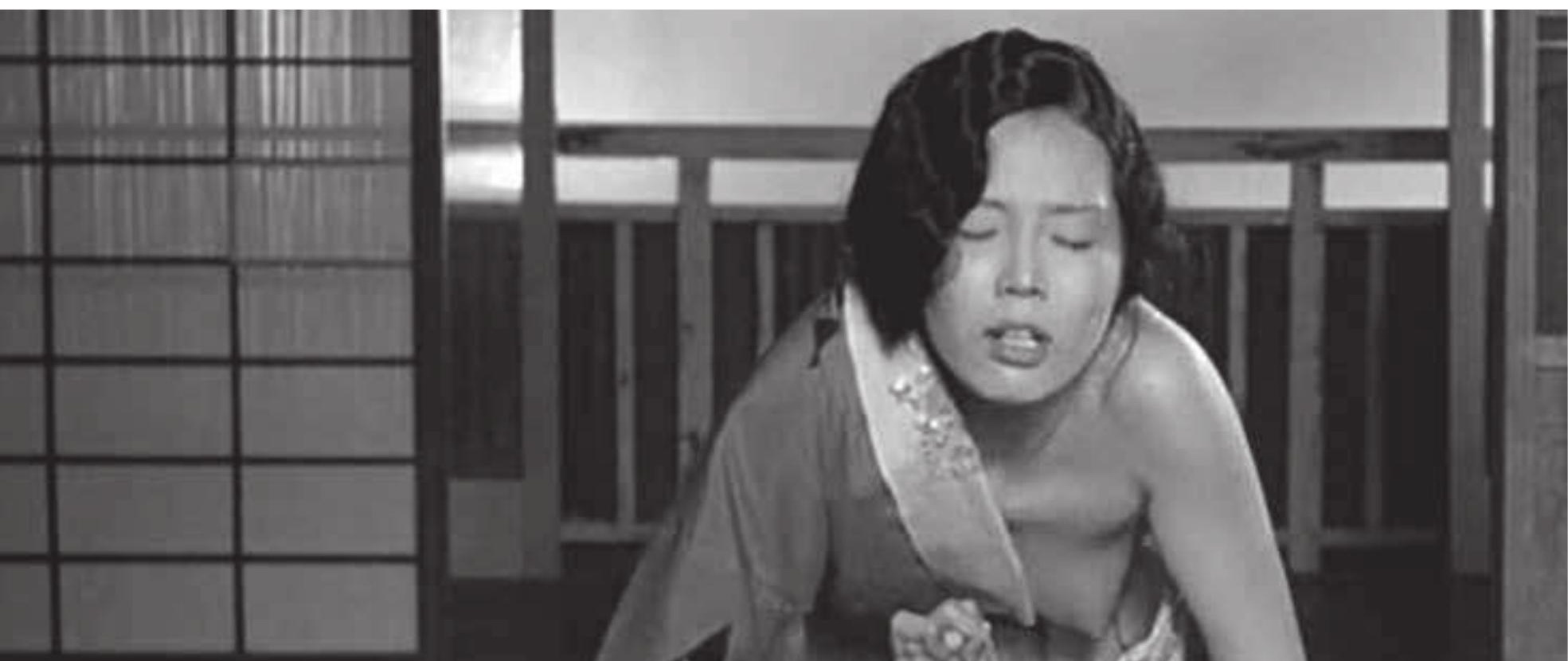

- Los personajes arriesgan su vida en la búsqueda del placer. 
tor de la dinámica erótica del filme. La composición casi ritual no mella en ningún momento la naturalidad de las conductas. El notable acompañamiento musical puntúa con mayor sequedad o emoción, según el caso, las diversas escenas, alternando con la parquedad de los diálogos y los instantes de silencio. Los planos se aproximan o distancian levemente sin violentar con impertinencia el curso de los acontecimientos. La tensión creciente es siempre soterrada sin menoscabo de un ritmo parejo y sostenido. No existen sobresaltos en la narración y los planos que reflejan proyecciones imaginarias (deseos, temores o sueños) no quiebran ni alteran la rigurosa continuidad del relato. La plasticidad del encuadre, de cálido cromatismo (rojos y naranjas,

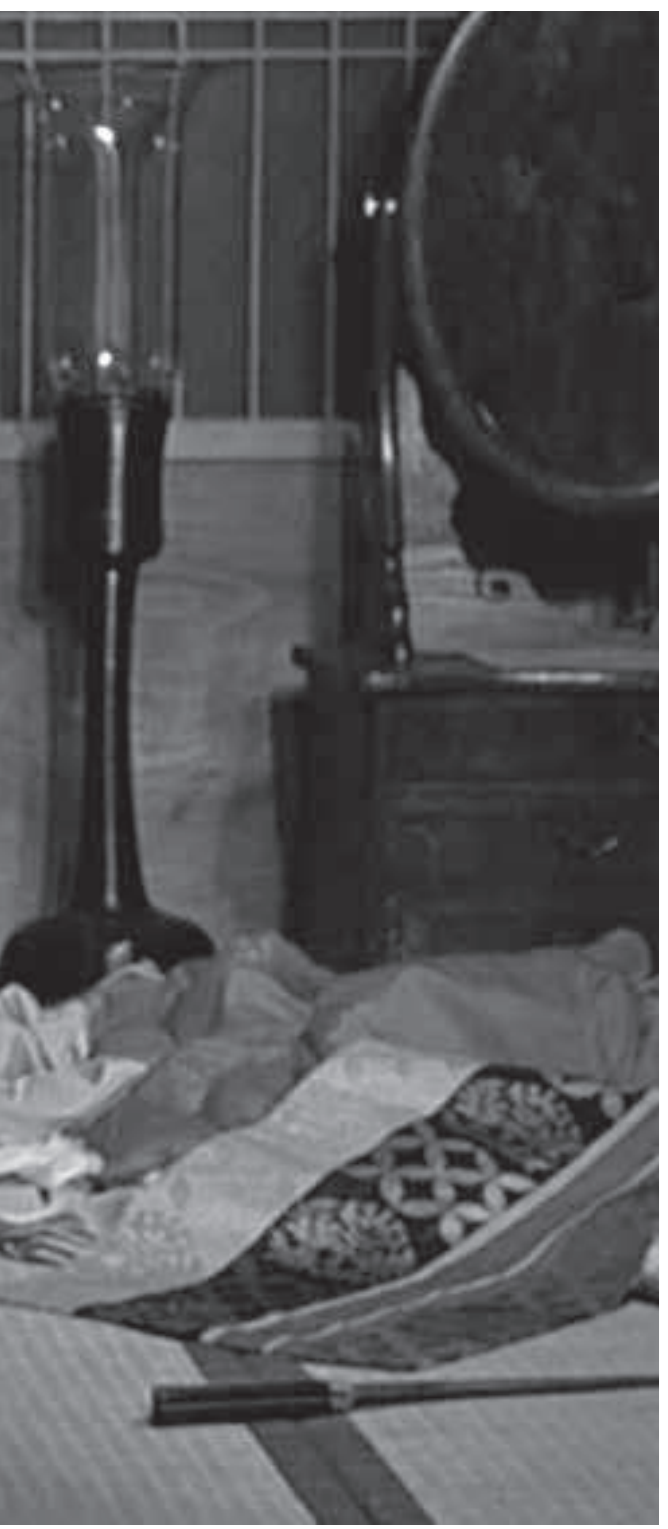

principalmente), inspirada en la tradición de los grabados eróticos japoneses, no es en ninguna imagen un fin per se, sino que tiene la funcionalidad encontrable, de otro modo, en las películas de Ozu y Mizoguchi, austeridad extrema el primero y decantación estilística el segundo.

El que, en definitiva, la acción fluya en verdaderos "cuadros eróticos" no le priva de una dominante radicalmente cotidiana, pero le aporta, sin desmedro de lo anterior, una dimensión litúrgica y ceremonial, digna heredera de un acervo que el mejor cine (y teatro) japonés ha cultivado a lo largo de su historia y que de una manera diferente también reaparece en Kamegusha, la sombra del guerrero, de Kurosawa. Esta dimensión litúrgica que nos remite no solo a una tradición cultural y a una manera de ser social, sino a una reflexión del cine como un espectáculo de la representación, está enraizada en la forma y el significado del filme plenamente fusionados: los cuerpos y los sentidos como objetos de una liturgia profana, la liturgia que la búsqueda placentera pone en marcha y que conduce a una verdadera y legítima comunión carnal.

\section{La fiesta de los sentidos}

El imperio de los sentidos propone una experiencia radicalmente inédita en el cine de auscultación erótica: una experiencia genuinamente sensorial, en una progresión libidinalmente creciente e intensa, que no tiene nada que ver con las efusiones seminales o la multiplicación de cuerpos de otros casos. Por lo pronto, el sexo irrumpe de manera poco ortodoxa desde las escenas iniciales. El viejo vagabundo que intenta reafirmar una perdida capacidad erectiva es uno de los primeros indicadores de un acercamiento diferente al sexo. Frente a ese genital inerte, expresión de decrepitud sexual, las escenas siguientes van a ser una continua afirmación de las potencialidades del sexo, aún en esa línea tenue que lo separa del riesgo de la muerte que aparece sugerido repetidamente con la presencia de navajas, cuchillos e instrumentos cortantes. Pero aun así, creo que el poder de eros asimila en el filme su contraparte agresiva y tanática. El camino que recorre la pareja allana, pese a las apariencias, las aristas destructoras. La autoinmolación final de Kichisan es tolerada y placentera y en ningún caso se trata de una castración de signo punitivo. Más bien, dentro del discurso que instala la película es la máxima afirmación de unidad de la pareja.

Ya la breve escena en la que Kichisan se pasa por la lengua los dedos con sangre menstrual de Sada abre las puertas a una permisividad total, es decir, a partir de ese momento cabe esperarlo todo, no hay sorpresa posible. Sin embargo, cada paso siguiente es un avance en el descubrimiento de las posibilidades placenteras, la conquista de un fragmento de territorio nuevo en la exploración del goce, una etapa en un aprendizaje erótico ajeno a lo programado o previsto, a lo conocido y calculado. Es decir, conforme avanza el curso de la relación, cada experiencia distinta es vivida por los personajes como la revelación de un "algo más". Esto, que constituye una constante en el relato, se acentúa en el pedido de Sada a Kichi-san para que copule con la anciana prostituta y, ciertamente, con las escenas que, poco a poco, desde que Kichi-san hace la propuesta, desarrollan el largo ritual del estrangulamiento. En cada momento es como si se planteara el desafío del "hasta donde se puede llegar" y con ello la superación de las trabas o controles que puedan evitar o postergar el avance. Cada objetivo ganado es, asimismo, el cumplimiento de una prueba, una cuenta más en el rosario libidinal de la relación, en esta especie de simbología cristiana al revés que podemos rastrear en el significado latente de la relación pasional de los personajes. Modalidad impenitente de penitencia. Sacrificio de signo feliz y gozoso.

Dentro de esa tónica, hay un rasgo, que no es una simple cuestión de matiz, sino algo más sustantivo, que define la relación: es ella la que opera como el personaje activante. Es verdad que las iniciativas iniciales corren a cargo del hombre, quien, por lo demás, es el amo y señor de la casa. Pero, rápidamente, una vez establecido el vínculo, es la 
mujer la que asume el aumento de dominio de la relación. Hay en ello un significado de desquite social (la inversión de la posición social de origen expresada en la acción de limpiar los pisos de rodillas) y de revancha sexual (la inversión de la ubicación inferior en el vínculo corporal), en una sociedad atávicamente clasista y patriarcal. Pero más que este significado reivindicador del rol femenino, sin duda presente, hay en el dominio que de a pocos Sada va ejerciendo un componente si se quiere más biológico ligado a la genitalidad femenina, a esa verdadera posesión del pene, a esa suerte de castración momentánea que en la cópula se realiza, a esa apropiación de la virilidad que la mujer obtiene. Cierto, también podría sugerirse otra lectura: el dominio de Sada como una superación del tabú del incesto y, en consecuencia, como una realización imaginaria del ayuntamiento con el padre. Hay, a este respecto, otros datos reveladores: la relación de Sada con el viejo maestro y la copulación de Kichi-san con la anciana, ambos en la línea del desempeño incestuoso. Pero vamos a dejar de lado esta lectura para insistir en la iniciativa femenina de Sada entendida como un proceso de absorción del hombre: desde la fellatio hasta la castración final, dos hitos del recorrido señalado, se anuncia tal propósito. La conducta de la mujer tiende en todo instante al apoderamiento, al control, recuérdese la escena en la que, camino a la casa familiar de Kichi-san ella no desprende la mano del miembro viril. A ello contribuye la relativa pasividad del macho que, en este caso, subvierte la supuesta normal sexual acerca del dominio masculino: es él quien, principalmente, se "deja hacer" y va siendo, de algún modo, succionado por la hembra.

Los signos más obvios de la enmasculación, es decir los instrumentos cortantes, apuntan en esa misma dirección. Es ella quien repetidamente hace uso de ellos o los acciona, casi siempre amenazadoramente, con el fin de reforzar su dominio sobre el macho, anticipando además, la apropiación final y definitiva.

En la progresión crispada de esa dialéctica amatoria se despliega la
El sexo se vive en los olores, en los sabores, en las presuntas aberraciones físicas, es decir, en el rechazo a la limpieza y a la exclusión del supuesto mal olor, en la comida humedecida por la secreción, en todos los sentidos que se ponen en juego.

sensorialidad (más que sensualidad) del filme: el sexo se vive también en los olores, en los sabores, en las presuntas aberraciones físicas, es decir, en el rechazo a la limpieza y a la exclusión del supuesto mal olor, en la comida humedecida por la secreción genital o directamente "empollada", en el deseo de recibir la orina por la vía vaginal..., en todos los sentidos que se ponen en juego sin exclusión. No digamos ya la vista, que, por ejemplo, en las miradas curiosas y ávidas de las criadas, ofrecen otro indicador del dispositivo sensorial que la película moviliza: el placer también está en mirar y en ser mirados y los personajes no lo ocultan. Pero por sobre todo ello, es la piel, el tacto, el cuerpo exultante, el que evidencia con mayor fuerza el ímpetu libidinal. Es en el accionar de los cuerpos y en esa sabiduría erógena, donde lo biológico y lo adquirido se confunden, que la trama pulsional encuentra su principal manifestación.

Por las vías apuntadas la película se dirige a su límite, aquel en el que Sada asume la posesión extrema del hombre a través del pene cortado, acto rigurosamente observado, pues dentro de la lógica del filme no cabía la elipsis, más aún cuando el último estrangulamiento, el mortal, que hubiera resultado una redundancia excesiva, es convenientemente elíptico. Para llegar a esta situación-límite, en un relato conformado por una verdadera sucesión de situaciones límite, el encuadre se densifica progresivamente, como si la acumulación del repertorio de sensaciones y el incremento de las pruebas que el filme expone fueran cargando la atmósfera física, dilatando el ritmo y accediendo a una temporalidad agobiante al máximo y a un espacio cada vez más cerrado y envolvente.

La densificación se radicaliza, por cierto, en las dos largas escenas del estrangulamiento de Sada a Kichisan y especialmente en la segunda, donde el relato alcanza su nivel de mayor intensificación (sensorial y dramática) y donde la misma planificación parece a punto de estallar. En esta escena confluye el ritual posesivo que llega a su punto de culminación en la operación enmasculatoria y se prolonga en el plano final de los dos cuerpos "eternizados", plano final en el que Sada y Kichi-san quedan unidos para siempre.

${ }^{1}$ León Frías, Isaac (mayo de 1982). "El ascetismo erótico de El imperio de los sentidos". Hablemos de Cine 75. Lima.

2 Razones de espacio me obligan a limitarme a hacer solo una breve referencia a Nagisa Oshima, el realizador japonés de la generación de los años 60 más altamente valorado por la crítica europea. Entre sus películas se cuentan Noche y niebla en el Japón (1969), El ahorcamiento (1968), El muchacho (1969), La ceremonia (1971), Hermana de verano (1972) y los dos Imperios, que alcanzaron la mayor resonancia entre la crítica extranjera. Que El imperio de los sentidos llegara a Lima es una consecuencia de su fama "pornográfica" y nada más.

${ }^{3}$ Otro intento de proporcionarle al porno un ropaje aún más estetizante, dentro de un erotismo de acentos semimórbidos, lo encontramos en las películas del polaco-francés Walerian Borowczyk, sin duda algo más consistentes que las de Just Jaeckin y epígonos. En Lima se estrenaron dos hasta inicios de los ochenta, la primera con cierto éxito a comienzos de 1979, en los albores de la apertura censora, y la otra con muy poco éxito en 1981; ellas son, respectivamente, Una mujer de la vida (La marge, 1976) y Tres mujeres inmorales (Les heroines du mal, 1979). 